\title{
Sexual Harassment: A Threat To Gradual Women Emancipation
}

\author{
Shamreeza Riaz \\ Faculty of Shariah \& Law \\ International Islamic University Islamabad
}

\begin{abstract}
This article is an attempt to highlight gender-based attitude of society towards women. Women comprise approximately $50 \%$ of the total population of Pakistan; Pakistan cannot afford to keep half of its citizens inactive and their potential as participants in development and progress untapped. Nothing more than the misogynist view of women as weak in physical power and deficient in mental faculties has marred the upward movement of societies. Women who defy this erroneous obscurantist conceptualisation and step into public domain are forced either to step back or to make compromises with the situation at the cost of their self-esteem and dignity. This deviant social behaviour is identified as sexual harassment of women. Sexual harassment of women exists beyond geographic spaces, across historic times, and today is prevalent in all societies, developed or underdeveloped. Women are sexually harassed within the safe havens of their homes too. This paper examines how a combination of factors, including religious interpretations, social norms, state negligence, and bad governance result in creating and than perpetuating an antiwomen environment that breeds sexual harassment and solidifies patriarchal structures. The last section of this paper cites reported cases of sexual harassment at workplace that happened between 2001 and 2011. Summing up, the paper offers some suggestions to minimise work-place sexual harassment of women.
\end{abstract}

\section{تلخيصِ مقالم}

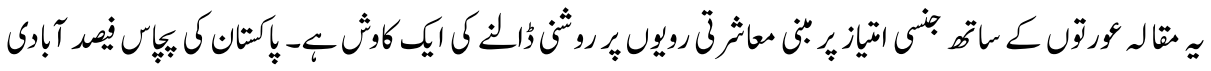

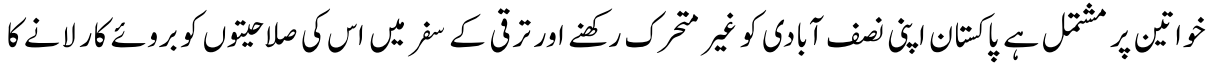

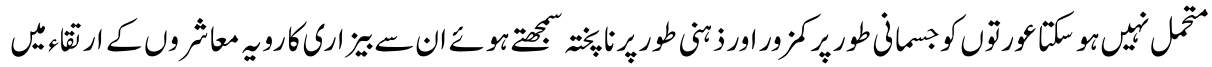

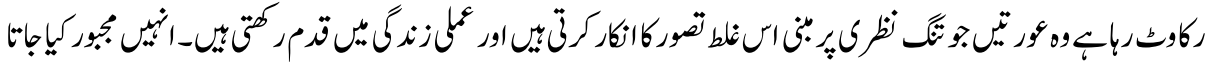

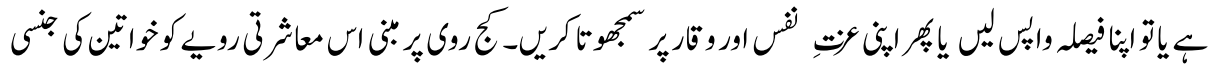

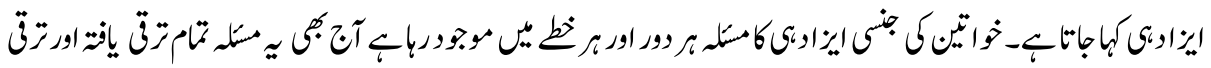

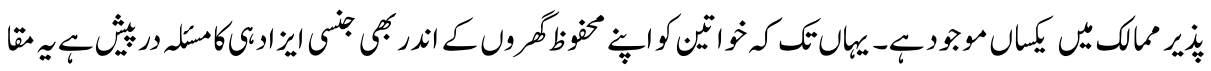

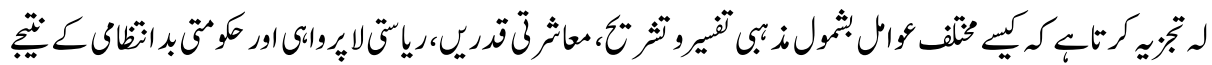

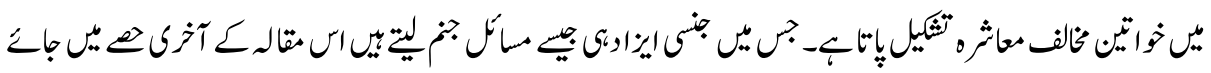

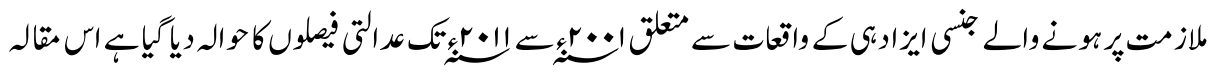

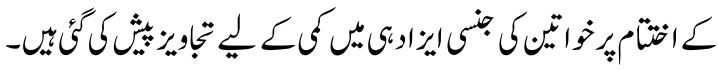




\section{Introduction}

Laws are formulated to put an end to injustice, crimes, volition of human rights and gender based violence in order to create a civilized society. The objective of law is to achieve justice and equality for all human beings without discrimination of class, sex, colour, and creed etc. At present, there are parallel legal systems, customs and practices that are prevalent in our society. These systems when joined together make men dominant whereas, subjugate and oppress women. It is not only limited to homes but at workplace and other places as well.

Women comprise $50 \%$ of the world population and they are contributing in $2 / 3$ of the world's work (Riaz, 2011). Women participation in shaping policy and decision-making process is a key feature for building peaceful and democratic society. As compared to other countries, women in Pakistan are reluctant to participate in every field of life. Since the very beginning of women's education in South Asia, all communities preferred teaching and medical profession for women. In Pakistan, these two professions are also preferred since last decade, however, in contemporary world, women join every profession but, sometimes, they are forced to leave their professions due to harassment at work place They face discrimination, gender based violence and similar dishonouring attitude from male members (Riaz, 2011). With the passage of time, harassment of women became common in Muslim societies and in Pakistan as well. At domestic level, legislation as well as plans and policies in this regard are introduced by Government whereas Senate has unanimously passed Harassment of Woman at Workplace Act in 2010 to protect women from harassment, when they are out of their homes.

Harassment of women in Pakistan is respectively a new issue as most of people did not consider it a crime and victims are forced to keep silent. Very few writers pay attention to address this issue in Pakistan. To know, actual situation of harassment in Pakistan, interviews were conducted in twin cities Islamabad and Rawalpindi with the women employees and employers of organizations, women activists, NGOs workers, educational institutions and with house wives. Group discussions were also held with teachers, students of Human rights and religious personalities. All these women, belonging from different fields, have highlighted different types of harassment. Few interviews will be added in this study in coming sections. Moreover, reports of Human Rights Commissions from 2001 to 2011 are reviewed to get statistical data on harassment cases. Additionally, most of data for this study is collected from Dawn News, BBC News, Express News, Front line News, Jang News and Pakistan Today. For clear understanding, it is necessary, here, to discuss harassment and its different forms which are prevailing in Pakistani society. 


\section{Gender Based Harassment}

Generally speaking, in Pakistan women, men and children face harassment from male members of society in different forms. This work will specifically highlight gender base harassment of women at different places. A woman is harassed when someone makes her feel uncomfortable or puts her in risk in any way, while she is doing her job or on her way to or from work or she is at home or at public gathering. She may be harassed by anyone whom she comes in contact with due to her work, due to family relation or even if she is not in contact with him and he is stranger for her. Such practices effects on women "regardless of age, relationship, disability, physical appearance, background and professional status" (International Trade Union, 2008). Harassment can happen anywhere at workplace, on street, at public gathering, institution and even at home. When a woman is harassed she feels threatened, humiliated and patronized. It creates an anti-mediating environment for her. Women, who are victims of the harassment, are always made to feel at fault and remain silent, moreover, if they raise their voice against it, they are threatened to face circumstances. If harassment is at workplace, it may affect women workers' morale and make them less efficient (International Trade Union, 2008). Harassment is basically a kind of violence against women which discourages her active participation. Before moving to kinds of harassment, it is necessary, here, to first explain violence against women for clear understanding of rest of the study.

According to Declaration on the Elimination of all Forms of Violence against Women 1993 (Declaration, 1993), violence against women is "an act of gender-based violence that results in, or is likely to result in, physical, sexual or psychological harm or suffering to women, including threats of such acts, coercion or arbitrary deprivation of liberty, whether occurring in public or in private life" (Declaration, Article 1). It states that gender based violence is an act that causes harm to a person due to his/her gender and women are primarily affected (Duvvury, 2009). This definition clearly explains that all forms of harassment whether physical, sexual or psychological come in the category of violence against women. Moreover, the United Nations declared that "it is not only a manifestation of gender-inequality, but often serves to enforce it" (Bott, 2005) as in many states it is often overlooked by institutions and community norms and is not defined in state laws (Heise, 1999). It includes sexual violence, domestic violence, sex-trafficking, harmful practices, such as female genital Mutilation/cutting, forced/early marriages, forced prostitution, sexual harassment and sexual exploitation (Duvvury, 2009). All these forms of violence exist in our society; however, this article will only highlight harassment of women.

There are different kinds of harassments which can be categorized as; 


\section{Sexual Harassment}

It is defined as unwanted, unwelcome and unasked sexual assault of woman by a male. It may occur within office, or outside the office or on roads or even at homes. Women face forced sexual harassment and in $20-30 \%$ cases, women remain silent because of their dignity and self respect. Sexual harassment can be physical, verbal, non-verbal and any other kind of harassment (International Trade union, 2008). Under the protection against harassment of women at workplace, Act 2010, sexual harassment means;

Any unwelcome sexual advance, request for sexual favors or other verbal or physical conduct of a sexual nature, when it interferes with work, is made a condition of employment or creates an intimidating, hostile or offensive work environment. Sexual harassment can take many forms and may include, but is not limited to: unwelcome sexual advances, the forcing of sexual attention, verbal or physical, on an unwilling person; or the attempt to punish the refusal to comply. Specific examples are: verbal harassment or abuse, subtle pressure for sexual activities, sexual advances in the pretext of narrating sexual incidents, unnecessary touching, patting, or pinching, leering at a person's body, constant brushing up against a person's body, demanding sexual favors accompanying by subtle or overt threats concerning employment or advancement, physical assault, including rape (Act.2010).

It only deals with the employed victims. Sexual harassment at other places such as homes, public places, streets and other places dealt under criminal law (amendment) act 2009 which defines harassment as "insult to the modesty of women" under section 509 of Pakistan Penal code.

\section{Physical Harassment}

Physical harassment may be defined as "unnecessary physical contact, touching or making homophobic comments" (International Trade Union, 2008) in public gatherings, on streets, in educational institutions or at home. It may include sexual "suggestive signals by sending unwanted text messages, emails or posting sexually-exploiting jokes on an office internet, mobile phone or by using any other mode"(2008). It may also include "touching, pinching, stroking, squeezing or brushing against someone, leering or ogling physical assault" (2008). It is observed during working ladies interviews that women are physically harassed by their colleagues through unwanted calls, emails and unwanted touching during their job (Riaz, 2011). Most of the women do not want to talk about this kind of harassment as men do not consider it harassment. 


\section{Verbal Harassment}

It is most common type of harassment in Pakistan. It includes "making sexual comments or innuendos, telling sexual jokes, or asking about sexual fantasies, making insults based on a person's sex or rating their sexuality, turning work discussions to sexual topics and requests for sexual favours, often related to promotion" (International Trade Union, 2008). This is also not considering as harassment however, it is common everywhere. Most of the time men use abusive and sexual language in offices, on streets and in markets during crossing with women. This kind of harassment is, almost, faced by every woman regardless of age, colour, cast and profession. Verbal harassment is common on streets especially in rural areas.

\section{Non-verbal Harassment}

Sometimes, male employees instigate woman by displaying pictures on calendars, PC desktop wallpaper or other sexually exploiting material. In Pakistan whistling and staring, which is also a kind of non-verbal harassment, is common and found at bus stops, public gathering, on streets and even in offices. Non verbal harassment also includes sexually exploiting SMS and Emails.

\section{Other Types of Harassment}

Many women are forced to work at unsuitable hours by their higher authorities, which could make their work dangerous. In an interview conducted for this study Sana, a receptionist, revealed that many times she is forced to stay at office even after office timings. Women suffer many types of harassment in these odds hours. Many other working women revealed in interview that they face different kinds of harassment from their higher authorities.

\section{Harassment of Women at Different Places}

In Muslim countries, sexual harassment is a heinous crime but ignored. In Shariah law, illegal sexual relationship, with or without consent, is considered a hadd crime and in national law for adultery, a corporal punishment is given. In contemporary Pakistani society, not only sexual harassment but many other types of harassment are deeply rooted like other western and European countries. This white elephant is so common in our country that it is not even considered a crime but an entertainment for guys. It is a kind of violence as the society turns a blind eye, when women complain about her harassment. They consider woman at fault rather than perpetrator. It is "an outrage that women would be subjected to this humiliation and veiled threat" (Nawaz, 2011). According to Nawaz, "[harassment] is like a white elephant in the room that no one sees" (Nawaz, 2011). 
Social Research and Development Organization (SRDO) prepared a research report which stated that "women face different kind of harassment, including inappropriate touching, making sexual comments and staring by male" (Qadar, 2011) in public gathering and especially in public transport. Although Government has taken positive steps to curb sexual harassment at workplace but the law which deals with public gathering and on other places is not clear. The punishment is very less as discussed in coming part of article; however, it is difficult to provide relief to the victims due to clear lack of implementation mechanisms (Qadar, 2011). For the enforcement of its mechanism, Government should take stringent measures to overcome the issue of harassment at workplace and especially in public gathering.

In Pakistani society, if a woman wants to go outside, she needs to accompany a male member of family such as her brother or father. Otherwise, she will not be respected by other men. A woman going alone is considered as she is walking alone for a purpose. Men come out from nowhere and start walking really close to her and start singing vulgar songs and passing exploiting comments which make woman feel uncomfortable. If she discusses the matter with her mother, she will reply her as, "[d]id I not tell you to wait for your brother to come home and take you? You wanted to hear all this and this is why you went outside alone" (Nawaz, 2011). Harassed women are discouraged to discuss the matter with others, or to take any action against the culprit as it would decrease victim's respect in society. In Pakistani society women are harassed in, public gathering, public transport, streets, educational institutions and at workplace.

\section{Harassment of Women in Public Gathering}

As we have discussed earlier, most common form of harassment takes place in public gathering. Eve teasing in public gathering is considered as form of recreation. Men take it as a source of enjoyment rather than considering a crime. Due to this social evil, a woman can't go outside without any chaperones. A husband, father or brother accompany her wife, daughter or sister whenever she wants to go out whereas it is cruel fact that he might involve in eve teasing elsewhere. Shazia Nawaz, a well known journalist added in an interview, "[y]ou respect your own mothers and sisters but that man standing on the street has no respect for your sisters or mother" (2011). In public gathering like in marriage ceremony, picnic points and at public parks, if a woman is harassed, she has to be silent to save her modesty otherwise the people will consider her to be involved in the case rather than punishing perpetrator. In public gathering staring and passing comments are most common forms of harassment in rural and urban areas. 


\section{Harassment of Women in Public Transport}

According to research report, conducted by Social Research and Development Organization (SRDO), 92 percent women are harassed in public transport in different forms, verbal, physical and sexual harassment (Qadar, 2011). Wide range of women answered that they would prefer to travel in only women transport even if they have to wait more than half an hour. A survey of 75 women reveals that "inappropriate touching, making sexual comments and staring by male passengers are common in buses" (Qadar, 2011). Sexual staring at public places and in public transport is so common that even most of men do not consider it as harassment. Research conducted for this paper shows that harassment of women in public transport is common due to the large population and due to lack of transportation system. In Pakistan due to lack of resources people cannot afford taxi or riksha, women have to travel in public buses with the high risk of harassment. According to survey, 59 percent women reported that one of the major reasons of harassment in public transport is less number of seats reserved for women passengers. Buses are so overcrowded that male can touch woman's body effortlessly. They blame ladies for this act however; if a woman harassed in public transport, she will prefer to keep silent for her honour. In Pakistani villages, schools and colleges are for away from their homes and female students have to travel. Many female students leave their education uncompleted due to sexual harassment in public transport whereas, some students hire riksha, which make their education very expensive. A nineteen-year girl student on condition of anonymity told the survey team, "She and her friend due to repeated incidents of harassment at the bus, they have started commuting in rickshaw even though it is quite expensive" (Qadar, 2011). The Government should take strict action to stop eve teasing in public places.

\section{Harassment of Women on Streets}

In whole world women are much more harassed on streets. Whenever, a man sees a woman alone, he will come out nowhere and start walking near to her. Whereas he will stare at her and start singing or will verbally harass her. It is reported by Shazia Nawaz in a news article that "[w]omen are harassed on the streets of Pakistan regularly and on daily basis. Men try to touch you and grope you whenever they find you alone. Women are rubbed against on regularly buses" (2011). Eve teasing is against the teaching of Shariah whether it is anywhere or in any form. The state must make legislation to stop harassment of women on streets as due to this crime, women prefer to stay at home which is against the very basic right of movement however; every human being has a right to move freely under constitution of Islam, state constitution and in the Universal Declaration of Human Rights (UDHR). It is further reported that police did not take roadside harassment as serious and due to the failure of authorities, who are responsible for implementing law and order, victims prefer to keep silent. Victims also do not want to 
involve in these cases as nothing would be result except lose of their modesty. A survey report conducted by Social Research and Development Organization (SRDO) reveals that $76 \%$ of the respondents bear the belief that harassment victims should remain silent however rest of the respondents suggested that harassment should immediately be reported (Qadar, 2011).

\section{Harassment of Women in Educational Institutions}

Harassment of women is even common in educational institutions. Female colleagues are not only harassed in educational institutions but students are also targeted by their male teachers. A teacher was suspended for harassing his students in the University of Peshawar. On student's complaint, university administration took notice of the incident, established an inquiry committee and punished the culprit (Shah, 2011). It was reported that some faculty heads are also involved in harassing female students (Shah, 2011). After this case, student from university reported that " [i]t can be a tip of the iceberg as fears of girl students, suppressed due to moral and social inhibitions since long, slowly go away and they speak up against senior teachers, involved in sexual harassment" (Qadar, 2011). A case was filed against the professor of the University of Punjab for harassing his student (Frontline, 2011).

A university student Saira, reveals her class experience with a male professor and said "[h]e would pat our backs, touch our hands whenever possible and stare at us suggestively" (Asjad, 2004). Moreover, on February 2012, same incident happened in International Islamic University Islamabad, where one professor harassed his student and university authorities forced him to leave the institute (Dawn, 2012). Harassment of women can be of any type; according to Zia Ahmed Awan, President of Lawyers for Human Rights and Legal Aid, even educated female strata of society have no understanding of harassment. He further added "[s]exual harassment does not just mean an act of physical offence. It starts from any gesture, stares or remarks that make women feel insecure and uncomfortable - while rape, molestation, incest etcetera remain the most severe forms of sexual harassment" (Asjad, 2011).

Many university students during their discussion revealed that they are harassed by their teachers and other administration staff. Working ladies during interviews admitted that they are harassed once or twice in their career by male staff members or bosses and sometimes by their clients. Additionally, students, teachers, working ladies and even house wives revealed that most of women are harassed in public places such as public transport. However, it is now common in all places, where male and female interact. The government must start training programs and awareness campaigns to create cohesive environment. There is a need to raise voice for rights and to suppress criminal activities of habitual offenders. 


\section{Harassment of Women at Workplace}

In Pakistani society like other societies, disease of harassing woman is not only limited to public gathering and in public transport. Unwelcome male attention also extends to workplace as well. Many well educated women are harassed by their bosses. Sometimes, she may be harassed by individuals with whom she interacts on work place for example, colleagues, management and clients. Harassment may occur to a woman regardless of her profession, age, physical appearance and socio cultural background (Abbasi, 2010). She may be any woman who is working as part time, daily wages, temporary or permanent. Harassment can happen anywhere at the workplace, which is; in the lunchroom, in rest and washroom areas; in staff rooms; on the production line; in an office. When a working woman is harassed she feels threatened, humiliated, patronized or harassed. It creates an anti-mediating environment for her. Victims of the harassment are always blamed for the action by society and if they complain they may find bitter consequences which leads to lose of job. It may affect women workers' morale and make them less efficient (International Trade Union, 2008). It is most important form of harassment, which needs to curb for bright future of woman and the better economic position of society.

\section{Legislation on Harassment of Women in Pakistan}

Harassment of women is one of the contemporary issues faced by Pakistani women at different places. It restricts women to come out from their homes for education, availing medical facilities and earning a livelihood (Asghar, 2009). When women move outside of their houses for their livelihood they are harassed, though not always, by their higher officials at their workplace. To stop discrimination against working women from our society, a body of law was required to protect rights of victimized women.

In 2000, women activists had started movement for the rights of women at workplace, however, no effort was made to end harassment of women from public gathering, public transport and on streets harassment (Riaz, 2010). In 2002, a bill was presented to amend Pakistan Penal Code section to safeguard working women from harassment but federal cabinet did not approve amendment by arguing that this law will be misused by female workers against their higher authorities (HRC, 2002). In January 2003, nine organizations working on women rights held a national consultation to finalize a draft law on harassment at workplace (HRC, 2003).

In 2004, Alliance Against Sexual Harassment AASHA, a group of nine civil society organization started working against this violence. In 2008, South Asian Women in Media (SAWM) held a preliminary meeting of female journalists in Lahore to discuss harassment and to devise possible support mechanisms the ministry of development proposed two bills to the cabinet on the $5^{\text {th }}$ of November, 2008 which were principally 
approved and were taken for the formal voting (HRC, 2003). Later on, after 4 months continuous struggle of women activists, bill was approved by cabinet on $3^{\text {rd }}$ February 2009 and in the month of April the bills were presented in National assembly (Yousaf, 2009). They presented two bills in the national assembly related to the issue of harassment of women: one was "the Protection against Harassment at the Workplace Bill" and "the Criminal Law (Amendment) Act of 2009".

Pakistan Penal Code (PPC), section $509^{1}$, previously dealt with harassment cases but it did not provide a complete or clear definition of women harassment which was not sufficient to discourage culprit. Under this section, imprisonment for crimes against women was up to one year or fine or both. By the struggles of women activists the previous law is amended as the Criminal Law (Amendment) Act, 2009. The Criminal Law amendment Bill related to sexual harassment was passed by the Senate with the approval of all major parties except some members of the religious parties, who walked out from the Senate. PPC section 509 was amended as an "insult to the modesty of women" which gave a justifiable definition of harassment to the court of law. Imprisonment was extended from one year to three years and a fine of 50,000 or both (Editorial, 2010).

The Criminal Law Amendment act deals with harassment cases anywhere, public gathering, public transport, street harassment and harassment by relative, however, lack of its implementation mechanism and non serious attitude of police in harassment cases, however, The Protection against Harassment of Women at Workplace Act provides implementation mechanism but without its proper implementation, this law is also vague.

Leading Pakistani legal experts and civil society activists struggled for legislation to protect women's right at workplace. Protection against harassment of women at workplace, Act 2010 intended to provide an opportunity to all organizations; public, private and civil society to develop a self regulatory mechanism whereby organisations could handle the problems related to harassment internally. Adoption of this code has become mandatory for all organizations and it requires the management to take charge of their institutional culture and make it dignified for both men and women (Masroor, 2008).

Protection against Harassment of Women at Workplace 2010 is not comprehensive law as it only covers government departments/organisations and female factory workers (Kakakhel, 2012). It does not protect women who are working in fields, at homes and even who are working in NGOs. In January 2012, the senate asked government to curb increasing cases of sexual harassment in NGOs and international NGOs (Kakakhel, 2012). In India, a smartphone application is launched by government to fight a rise against sexual harassment cases (Express News, 2011). If a female feels at risk she can alert her family, friends immediately by using application. In Pakistan, there is a need to introduce such system. 


\section{International Legislation to Stop Sexual Harassment}

All over the world, Women activists have raised this issue. International organization has now got recognition to stop sexual harassment of women especially at workplace. International Labour Organization, ILO Convention against 'discrimination in employment' deals with "sexual harassment at work, and for women workers it is a major form of discrimination. In 2003, the ILO's Governing body adopted a code of practice on workplace violence in service sectors that offers guidance against sexual harassment of woman. The ILO's 'Campaign for Decent Work' includes sexual harassment as an aspect of health and safety, discrimination, and a violation of workers' basic rights” (ILO, 1997).

The UN Convention on the Elimination of All Forms of Discrimination against Women (CEDAW) declares that States should eliminate discrimination against women at work place (CEDAWA, 1979). Pakistan became signatory to this convention on 12 Mar.1996 and bound to follow its provisions. Similarly, in Beijing, a program was started for action declaration in 1995. United Nations' Women's Conference in Beijing drew up a Platform of Action of objectives and actions to advance women's rights, including outlawing sexual harassment at work (Declaration, 1995). The European Union's 1991 'Code of Practice' called on Member States to promote "awareness of sexual harassment and take measures against it, and a directive prohibiting, sexual harassment was adopted in 2002" (Code of Practice, 1991). The "Inter-American Convention on Violence against Women' says that 'States must promote and protect women's rights to be free from violence. It suggests legal measures to prevent this occurring and ensure victims have access to "just and effective" remedies" (Convention).

This part of article focused national and international legislation against harassment of women at workplace, public gathering, on streets, at public transport and at homes. It is equally important to discuss here that, there are other forms of harassment which are ignored during formulation of the act by legislature. ${ }^{2}$ Moreover, harassment at public gathering, public transport, on streets harassment and even harassment at home is defined in criminal law (amendment) act but lack of implementation mechanism, the law has no value. Senate has only passed legislation which needs more clarity in its definitions and in its mechanism. Government must take strict actions against culprits to discourage others.

\section{Statistic View of Harassment of Women}

This part of study will highlight statistic data of last decade harassment cases happened at workplace. Here, it is necessary to mention that harassment at other places, at public gathering; public transport; on street; harassment by male relatives at homes, was never reported as society does not consider it crime. This part will only include harassment 
cases at workplace which is revealed by previous reports and literature on the issue. Harassment cases from 2001-2011 will be discussed in this part.

In 2001, a survey was conducted by female students of the Karachi University's Centre for Excellence in Women's Studies and it was revealed in its report that 61 percent of working women did not feel protected in the work environment (HRC, 2001). A previous survey by the Centre had found that out of 80 working women, between the ages of 20 and 50 working in Karachi offices, 16 percent frequently changed jobs due to the work environment while another 16 percent had faced harassment continuously. A survey mentioned in annual report of Human Rights Committee in 2002 revealed that 62 percent of women secretarial workers face harassment or hostile working environment (HRC, 2002). Most of the time factory workers are harassed during their work hours by their male colleagues. A survey was conducted among 200 Karachi base working women in 2003 which revealed that 93 percent women face harassment (HRC, 2003) in some forms as mentioned in first part of article. They admitted that 45 percent face psychological abuse, 33 percent suffered physical and 25 percent face sexual abuse (HRC, 2003). With no law at place and increasing cases to harassment, women prefer to home based work and void active participation in different fields.

According to statistic provided by the Secretary of law and justice commission 78 percent working women face harassment in 2004 (HRC, 2004). Reports of many working organizations for women's rights revealed that doctors, bankers, sales girls, receptionist, maids, nurses, domestic workers, official workers brick kiln and field workers face harassment in any form. A research conducted by Alliance against sexual harassment of women at workplace disclosed that 91 percent of domestic female workers face harassment (HRC, 2004). A code of conduct was devised by AASHA to protect women from harassment. Many efforts were taken to curb this white elephant from society, which remained a hurdle confronted by thousands of women. Harassment of women were not only limited to workplace and public gathering. Similar cases took place in Sindh assembly, where political leaders harassed legislator and other female members (HRC, 2005), After growing cases of harassment, many NGOs draw attention to the issue and raised voices for harassment law.

This shocking trend was increasing day by day and many cases were reported. In 2008, only 808 cases of sexual harassment cases was reported which includes 350 rape cases, 445 gang rape cases and 13 of stripping (HRC, 2008). The ratio of other form of harassment was countless as many women comes out of their homes and joins traffic police, national highway authority tool tax service, call centres and bus service, where every women were used to harass once a day and offenders take it a source of recreation rather a crime. According to human right committee report, 2903 women were rape this 
year whereas many others were harassed at workplace, on streets, at public gathering, at public transport and at their own homes by their male relatives (HRC, 2008).

After long struggle of women activists and different organizations working for women's rights, a bill was passed in 2010. According to the law, harassment of women at workplace will be dealt under the protection against harassment of women at workplace act 2010 and harassment at public places and everywhere will be dealt under criminal law (amendment) act. It was a great achievement for women activist; however, the struggle does not end here. Firstly, there is a need of balance between laws made and in its implementation mechanism. For the public awareness of harassment laws in Pakistan, services of women activists and government are still needed as law is vague without its proper implementation. Secondly, to enjoy the protection of law and to be treated in accordance of law, administration of justice is required. Protection against harassment of women at workplace act 2010 provides an implementation mechanism, for more details on its mechanism please see this author article (Riaz, 2011). After the enforcement of recently passed act, many cases were reported in newspapers in year of 2011 and 2012 which revealed lack of implementation mechanism and also revealed that women were unable to reap the benefit from newly passed law due to lack of awareness. AASHA is trying hard to aware people about current law. They arranged many seminars, training sessions and awareness campaigns in last two years. In the federal ministries committees are formed for implementation of law. State bank and higher education commission issued policies, which mean code of conduct and implementation of law will be ensured in all banks and universities. A National Implementation Watch Committee, NIWC, is established to ensure that law is institutionalised. It is also admitted fact that only one organization, AASHA, is not able to institutionalised the law and provide complete awareness of legal frame work in private and public sector. All organizations and government must take action to ensure the law.

\section{Recommendations and Conclusions}

The findings and conclusion set out in this research paper give rise to a number of recommendations that are designed to assist the Government that has obligations to respect, protect and fulfil the rights of women within and outside of their house. Government and other women activists may make their efforts to enforce legislation regarding harassment of woman at the best of their level. Following points need concern from Government, NGOs and from the citizens,

- Government should take strict measures to tackle the issue of harassment of women in public transport, public gatherings and on streets. Existing law is not sufficient to safeguard women from most common form of harassment. The government should show more initiative in enactment of new law for all forms of harassment. 
- Laws alone will not end harassment of or violence and discrimination against women. The government should ensure that mechanisms for redress for female victims of violence, harassment and discrimination are effective and easily accessible.

- Women should immediately report the case, when she is harassed in public gathering or elsewhere and society should encourage women rather considering her wrong.

- $\quad$ Police should take immediate action against the culprit; especially police must take roadside harassment of women seriously.

- Government must take strict action for an organized implementation mechanism to provide relief to the victim and to ensure their safety after filling a case.

- Government must set a helpline to specifically deal with the cases of harassment in public transport and start some app system like India to report case immediately.

- Need to strengthen the capacity of law enforcement and fare distribution of justice among women and it would be possible when they know their rights and safeguards provided by law.

- Needs an extensive input from civil society organization including women rights organizations, legal experts, labour rights bodies and human rights leaders.

- Involvement of citizens of state in legislation is a good step, but there should be follow-up programmes from the Government.

- Media can play a positive role for the implementation of the legislation, different programmes and campaigns should start with the help of Government at national level to spread the awareness of the law. Media can play a role to change the mind of society on this issue.

- Victims should, discuss with their family members and file a case against the culprit.

- An awareness workshop should be held within each police station to know about the policies and legislation regarding harassment.

- Legal aid / counselling should be provided to the victim free of cost.

It is concluded that harassment of women is considered a crime. Many steps are taken to curb it on International and National level however; positive results of legislation can be only achieved with its strong implementation mechanism. Government authorities should pay much attention to end injustice in cases of sexual harassment. It is a need of time to start awareness campaigns for the citizens of Pakistan to end violence against women from society. 


\section{End Notes}

1. "Insulting the modesty of a woman: any sound, gesture, or exhibition of any object intending to insult the modesty of a woman" (S.509 PPC)

2. For all forms of harassment at anyplace, only previous law is amended as "the Criminal Law (Amendment) Act, 2009." The Criminal Law amendment Bill (which is related to sexual harassment) was adopted by the Senate with the support of all major parties, but with members of the religious parties staging a walkout or absenting themselves. Pakistan Penal Code section 509 was amended as an "insult to the modesty of women" and gives a clearer definition of harassment to make it justifiable before a court of law. Imprisonment was extended from one year to three years and a fine of 50,000 or both. However, it does not provides implementation mechanism to curve harassment on streets, public gathering, public places, public transport and even at homes from male relatives.

\section{References}

Abbasi, (2010), Interview with Amir Abdullah Abbasi, Joint Secretary, Islamabad Bar Council, in Islamabad.

Act, (2010), The Protection against Harassment of Women at Workplace Act 2010, http://www.qau.edu.pk/pdfs/ha.pdf, retrieved on 16/9/2012.

Asghar, Raja, (2009), Higher Penalty for Women's harassment approved, DAWN News, 05, Nov, 2009.

Asjad, Nadia, (2004), Pakistan’s Taboo On Sex Abuse, BBC News, Nov.17, 2004.

Beijing program for action Declaration, United nation Women's Conference 1995, retrieved on $10 / 5 / 2011$.

Bott, Sarah, Morrison, Andrew \& Ellsberg, Mary, (2005), Preventing and responding to gender-based violence in middle and low income countries: a global review and analysis, World Bank Policy Research Working Paper 3618.

Code of practice (1991), European Union, 1991, retrieved on 10/5/2011, http://eurlex.europa.eu/LexUriServ/LexUriServ.do?uri=CELEX:52005DC0217:EN:NOT. 
Convention on the Elimination of all Forms of Discrimination against Women 1979, United Nations Department of public Information, retrieved on 19/6/2011, http://www.un.org/womenwatch/daw/cedaw/text/econvention.htm.

Dawn Editorial, A landmark move, DAWAN News, Jan22, 2010.

Dawn news, (2012), Sex scandals have rocked the International Islamic University Islamabad (IIUI) in recent months, with several faculty and staff members accused of preying upon the vulnerable female students or juniors, February, 2012.

Declaration on the Elimination of Violence against Women, (1993), article 1, retrieved on, 16/3/2012, http://www.un.org/documents/ga/res/48/a48r104.htm.

Duvvury, Nata, (2009), Keeping Gender on the Agenda, Gender Based violence, Poverty And Development, Joint Consortium on Gender Based Violence, NUI Galway, retrieved on 13/12/2011 http://www.realizingrights.org/pdf/Keeping_Gender_on_ the_Agenda.pdf.

Express News, Smartphone app launched to fight a rise in sexual assault cases, retrieved on, 14/6/2012, http://expressnews247.blogspot.com/2011/12/smartphone -applaunched-to-fight-rise.html.

Frontline with Kamran Shahid, Zem Tv, retrieved on 1/14/2012, http://www.youtube.com /watch?v=5Bgzw5dSocY.

Heise, Lori, Ellsberg, Mary, \& Gottemoeller, Megan, (1999), Ending Violence Against Women, Population Reports, Volume XXVII, Number 4, Series L, Number 11, retrieved on 16/1/2012.

HRC, (2001), Annual Report Human Rights Commission, Maktaba Jadeed Press: Lahore.

HRC, (2002), Annual Report Human Rights Commission, Maktaba Jadeed Press: Lahore.

HRC, (2003), Annual Report Human Rights Commission, Maktaba Jadeed Press: Lahore.

HRC, (2004), Annual Report Human Rights Commission, Maktaba Jadeed Press: Lahore.

HRC, (2005), Annual Report Human Rights Commission, Maktaba Jadeed Press: Lahore.

HRC, (2008), Annual Report Human Rights Commission, Maktaba Jadeed Press: Lahore. 
Inter-American Convention on the Prevention, Punishment and eradication of Violence against Women, Department of International Law, Organazation of American State , Washington D.C, retrieved on 10/5/2011, http:/www.oas.org/juridico/ english/treaties/a-61.html.

International Trade Union Confederation, (2008), Stopping Sexual Harassment At Workplace, 1, retrieved on 10/05/2012, http://www.ituccsi.org/IMG/pdf/ Harcelement_ENG_12pgs_BR.pdf.

Kakakhel, Ijaz, Govt asked to take notice of sexual harassment in NGOs, Sunday, January 29, 2012.

Masroor, Aroosa, Staying silent no more, Jang News, December 28, 2008.

Nawaz, Shazia, (2011), Sexual Harassment Of Women On The Streets Of Pakistan, Let us Build Pakistan, retrieved on 12/3/2012, http://criticalppp.com/archives/49700.

Qadar, Abdul, (2011), Lades only?, Pakistan Today, 24 May 2011.

Shah, Sadia Qasim (2011), Varsity Teacher Suspended For Harassing Girls, Dawan News, May 18,2011.

Shamreeza Riaz, (2010),Implementation Mechanism - Protection against Harassment of Women at Workplace, Hamdard Islamicus, Vol. XXXIV, No.2.

Yusuf, Huma, (2009), Beyond Harassment, DAWN News, 15 Nov, 2009.

Shamreeza Riaz is Teacher/Research Associate in the Faculty of Shariah \& Law International Islamic University Islamabad. 